\title{
A CATAMNESTIC STUDY ON 50 PATIENTS WITH COMPLETE IRREVERSIBLE LESIONS OF THE SPINAL CORD
}

\author{
By H. WAHLE, M.D. \\ Universitäts-Nervenklinik Köln
}

\section{INTRODUCTION}

Over the last ten years one has observed an increasing realisation of the need for a competent treatment of paraplegics in the German Federal Republic (Kreusch et al., I957; Meinecke, I960; Jochheim \& Wahle, I962; Paeslack, I962). However, compared with England and America the development of centres for paraplegics is rather belated. This is the reason we were able to examine the medical and social situation of paraplegics, who only in a few instances were treated in special centres such as those maintained by the Employers' Liability Insurance Association.

Such a follow-up study seems to be useful for it reveals the need for accelerating the establishment of special centres for paraplegics. On the other hand, such a review gives a basis for comparison of our own results with those of well-established centres with greater experience.

Our follow-up study concerns 50 paraplegics with complete, irreversible lesions of the spinal cord and the cauda equina. Most of these cases were taken from a more detailed and more comprehensive study in I960 (Wahle, 1963).

The author is indebted to the 'Bundesministerium fur Arbeit und Sozialordnung' for its support of this study. Certainly the figure of 50 paraplegics is very small as compared with the large series published in England and the U.S.A., but there is no reason to believe that we could have gained better results by including more cases.

\section{CLINICAL MATERIAL}

The basic material included more than I 50 medical notes, legal medical reports and social reports of the various Health Services. These reports were fairly complete during the first two years after the onset of paraplegia as most of our paraplegics had been in hospital practically the whole time. Moreover, we re-examined all our paraplegics whether they were in hospital or at home. From this we were able to complete our follow-up reports.

Our case study contains several causes of paraplegia: Traumatic lesions of the spinal cord or cauda equina in 40 cases, myelitis in five cases and neoplastic spinal processes in five further cases. Four out of five of the latter had been operated on before rehabilitation because of a tumor of the spinal cord and because of a kyphoscoliosis in spina bifida. I958.

Our 50 cases had been paralysed by accident or disease during the years 1952-

At the onset of paraplegia, the ages of $4 \mathrm{I}$ cases out of the 50 varied between I 5 and 34 years, and only nine cases belonged to the age-group between 35 and 54 .

There were 34 male and I 6 female paraplegics.

Authorities responsible for hospital costs had been: 
In 25 cases Welfare Authorities.

In 23 cases Employers' Liability Insurance Association (Workman's Compensation).

In 2 cases Private Insurance Companies.

\section{TIME YARDSTICK}

Our continuous notes enabled us to recognise the medical and social state of each paraplegic after variously chosen intervals from the beginning of the paraplegia. It was by this method that we could compare our results with those of other authors. For our observation-periods we have chosen the duration of rehabilitation in hospital as given by Guttmann (1956a) and reported in a review in Germany by Kreusch et al. (1957). We took these standards of time because we are convinced that we should be able to achieve an equally quick result in Germany. These periods of rehabilitation in hospital have been defined as 5, 7, or 12 months for complete paraplegia according to the level of the lesion.

In our review we call the time from the onset of the paraplegia (stage I) until the aimed at end of the rehabilitation (stage II) section A. This is the normal period of hospital treatment according to Guttmann's statistics (1956a, I959a). However, because of the circumstances in the German Federal Republic we had to account for a prolongation of these times. Therefore, we have also given the results of rehabilitation after twice the time. This next period we call section $B$. It reaches from stage II to stage III. At this point IO, I4 or 24 months have gone by since the beginning of the paraplegia.

TABLE I

Duration of Observation and Level of the Lesion

\begin{tabular}{|c|c|c|c|c|c|}
\hline & $\begin{array}{c}\text { Stage } \\
\text { I }\end{array}$ & $\begin{array}{c}\text { Section } \\
\text { A }\end{array}$ & $\begin{array}{l}\text { Stage } \\
\text { II }\end{array}$ & $\begin{array}{c}\text { Section } \\
\text { B }\end{array}$ & $\begin{array}{l}\text { Stage } \\
\text { III }\end{array}$ \\
\hline $\begin{array}{l}\text { Duration } \\
\text { of } \\
\text { Paralysis }\end{array}$ & & $\begin{array}{l}12 \text { months } \\
7 \text { months } \\
5 \text { months }\end{array}$ & $\begin{array}{l}\text { Di-D5 } \\
\text { D6-Di2 } \\
\text { LI-L4 }\end{array}$ & $\begin{array}{l}24 \text { months } \\
\text { I } 4 \text { months } \\
\text { Io months }\end{array}$ & $\begin{array}{l}\text { DI-D5 } \\
\text { D6-Di2 } \\
\text { LI-L4 }\end{array}$ \\
\hline
\end{tabular}

\section{CATAMNESTIC RESULTS}

Residual Syndromes. All patients had complete and irreversible motor and sensory paralysis below the level of the cord lesion, which can be summarised as follows:

$$
\begin{array}{lccccc}
\text { Level of } & \mathrm{C}_{4}-\mathrm{C} 8 & \mathrm{DI}_{\mathrm{I}} \mathrm{D}_{5} & \text { D6-Di2 } & \mathrm{LI}_{\mathrm{I}} \mathrm{L}_{4} & \text { Total } \\
\text { paraplegia } & - & \text { I I } & 26 & \text { I3 } & 50
\end{array}
$$

It is important to point out that there are no patients with complete cervical lesions, the reason being that in Germany, most patients with cervical lesions died during the first two years after the injury.

Recently published statistics, however, show an embarrassing picture. As Guttmann reported at the 4th International Congress of Physical Medicine in Paris in 1964, 506 tetraplegics, treated between I944 and I964 in Stoke Mandeville, 
revealed a death rate of only 34 out of I 53 patients with complete cervical lesions (22.2 per cent.). In England, U.S.A. and Canada the life expectancy of tetraplegics shows a considerable increase in the last IO-I 5 years. Of course in stage II and III the motor paralysis of our paraplegics was so considerable that movement was only possible with the aid of a wheelchair or with the aid of braces and arm crutches. Twenty-seven paraplegics had spastic paralysis and 23 paraplegics had flaccid paralysis.

The disturbances of sensibility concerned all modalities. There was also loss of control of the bladder and bowel in all patients. The paralysis of the bladder and bowels was of upper motor neurone type in 27 cases and of lower motor neurone type in 23 cases.

Details of the bladder disturbances are shown in Table II.

TABLE II

Bladder Function in 50 Paraplegics

\begin{tabular}{|c|c|c|c|c|}
\hline & & $\underset{\text { Stage }}{\text { I }}$ & $\begin{array}{l}\text { Stage } \\
\text { II }\end{array}$ & $\begin{array}{l}\text { Stage } \\
\text { III }\end{array}$ \\
\hline $\begin{array}{c}\text { Total retention of urine } \\
\text { No incontinence }\end{array}$ & $\cdot$ & 49 & I2 & 4 \\
\hline $\begin{array}{l}\text { Micturition only after bladder expression } \\
\text { No incontinence }\end{array}$ & . & - & 2 & 3 \\
\hline $\begin{array}{l}\text { Uncontrolled micturition at short intervals } \\
\text { Intermittent incontinence }\end{array}$ & . & I & 35 & 39 \\
\hline $\begin{array}{l}\text { Automatic micturition at long intervals } \\
\text { Intermittent incontinence }\end{array}$ & . & - & I & 4 \\
\hline Total & . & 50 & 50 & 50 \\
\hline
\end{tabular}

The results show a delayed development of an automatic bladder (Wahle \& Bischof, I96I). In stage II when, with competent treatment, the rehabilitation should be finished, 24 per cent. of our cases had retention of urine; but also after the double period, in stage III, the number of paraplegics with good automatic bladder function, i.e. long intervals, two hours and more, was very small (8 per cent.). In stage III more than 70 per cent. of the cases had uncontrolled micturition at short intervals. They had passive or active intermittent incontinence.

It is, therefore, clear why nearly all our paraplegics were dependent on special aids. Even at stage III-the average time was I5 months after the onset of the paraplegia-the number of cases who needed no help was extraordinarily small (6 per cent.) (Table III).

At the same time-stage III-42 per cent. of our cases used catheters (suprapubic drainage permanent catheters, or intermittent catheters). The most suitable accounts with which to compare our results are those of Comarr (1959). About I2 months after the beginning of paraplegia not more than 6 out of his 53 cases with complete lesions required a catheter ( $\mathrm{I} \cdot \mathbf{3}$ per cent.). This difference clearly demonstrates how the disturbances of the bladder function can be corrected by competent treatment. 
TABLE III

Special Aids to Compensate for the Disturbance of Micturition in 50 Paraplegics

\begin{tabular}{|c|c|c|c|c|c|c|c|c|}
\hline & \multicolumn{6}{|c|}{ Stage II } & \multirow[b]{2}{*}{ No aid } & \multirow{2}{*}{$\begin{array}{c}\text { Total } \\
\text { II }\end{array}$} \\
\hline $\begin{array}{l}\text { Special } \\
\text { aids }\end{array}$ & $\begin{array}{c}\text { Perma- } \\
\text { nent } \\
\text { catheter }\end{array}$ & $\begin{array}{l}\text { Supra- } \\
\text { pubic } \\
\text { fistula }\end{array}$ & $\begin{array}{l}\text { Inter- } \\
\text { mittent } \\
\text { catheter }\end{array}$ & $\begin{array}{c}\text { Perma- } \\
\text { nent } \\
\text { flask }\end{array}$ & $\begin{array}{l}\text { Pad or } \\
\text { rubber } \\
\text { pants }\end{array}$ & $\begin{array}{l}\text { Urinal } \\
\text { and } \\
\text { clamp }\end{array}$ & & \\
\hline $\begin{array}{l}\text { Male } \\
\text { Female }\end{array}$ & I3 8 & $\begin{array}{l}2 \\
\mathrm{I}\end{array}$ & $\begin{array}{l}5 \\
6\end{array}$ & 5 & $\bar{I}$ & $\begin{array}{l}8 \\
-\end{array}$ & I & $\begin{array}{l}34 \\
\text { I6 }\end{array}$ \\
\hline $\begin{array}{r}\text { Male and } \\
\text { Female }\end{array}$ & $2 \mathrm{I}$ & 3 & I I & 5 & I & 8 & I & 50 \\
\hline Total & & $\begin{array}{l}35 \\
\text { th cathet }\end{array}$ & & & cathe & 5 & & \\
\hline & & & & STAGE III & & & & Total \\
\hline $\begin{array}{l}\text { Special } \\
\text { aids }\end{array}$ & $\begin{array}{l}\text { Perma- } \\
\text { nent } \\
\text { catheter }\end{array}$ & $\begin{array}{l}\text { Supra- } \\
\text { pubic } \\
\text { fistula }\end{array}$ & $\begin{array}{l}\text { Inter- } \\
\text { mittent } \\
\text { catheter }\end{array}$ & $\begin{array}{c}\text { Perma- } \\
\text { nent } \\
\text { flask }\end{array}$ & $\begin{array}{c}\text { Pad or } \\
\text { rubber } \\
\text { pants }\end{array}$ & $\begin{array}{l}\text { Urinal } \\
\text { and } \\
\text { clamp }\end{array}$ & No aid & III \\
\hline $\begin{array}{l}\text { Male } \\
\text { Female }\end{array}$ & $\begin{array}{l}5 \\
3\end{array}$ & $\begin{array}{l}2 \\
-\end{array}$ & $\begin{array}{l}3 \\
8\end{array}$ & $\begin{array}{l}4 \\
\mathrm{I}\end{array}$ & $\overline{2}$ & $\begin{array}{l}\text { I9 } \\
-\end{array}$ & $\begin{array}{l}\text { I } \\
2\end{array}$ & $\begin{array}{l}34 \\
\text { I6 }\end{array}$ \\
\hline $\begin{array}{r}\text { Male and } \\
\text { Female }\end{array}$ & 8 & 2 & I I & 5 & 2 & I9 & 3 & $5^{\circ}$ \\
\hline Total & & $\begin{array}{c}2 \mathrm{I} \\
\text { th cathet }\end{array}$ & & & cathet & free & & \\
\hline
\end{tabular}

This paper deals only briefly with the disturbances of the bowels and their treatment. Most of our paraplegics had complete loss of sensation and loss of control of their rectal function, and suffered from more or less severe constipation. To overcome this constipation it was necessary to have a digital evacuation by a nurse at stage II for 22 out of 50 paraplegics, and at stage III for I 6 out of 50 paraplegics.

This result does not correspond to the experience of Guttmann (I959b), 'that a satisfactory bowel régime can be achieved in the spinal man'. Only in a few cases may digital evacuation sometimes be necessary. 
Complications of Paraplegia. The most important aims of the treatment of paraplegics are to avoid the development of contractures of the joints, pressure sores and urinary infections (Guttmann, 1953, 1956). Accordingly it is a criterion of experienced and careful nursing, if there are no, or rare, complications.

How common and how extensive were the complications in our 50 cases?

\section{Contractures}

TABLE IV

Frequency and Degree of Contractures in Both Legs

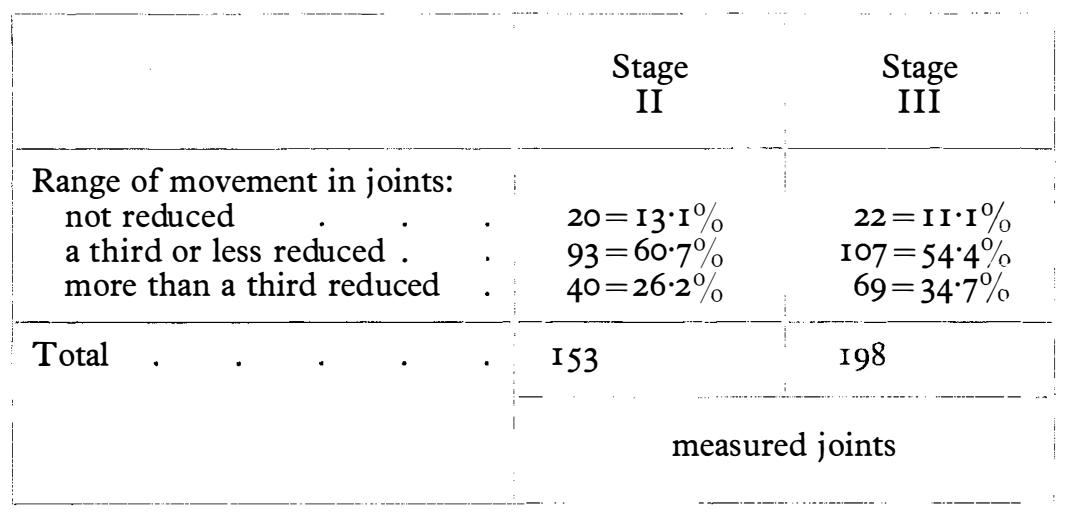

Most of the paraplegics had contractures of their paralysed legs at stage II and stage III. We have to add that there were just as often contractures in paraplegics with flaccid paralysis as in paraplegics with spastic paralysis. This was surprising, since-according to common medical experience-contractures are easier to avoid in flaccid paraplegics than in spastic cases.

\section{Pressure Sores}

TABLE V

Frequency and Extent of Pressure Sores

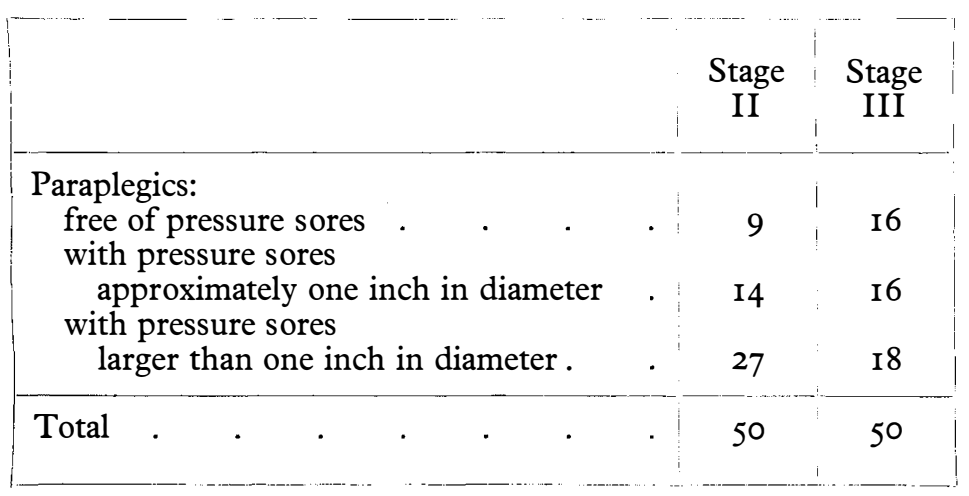

At the time, when rehabilitation in hospital should be finished, 82 per cent. of our paraplegics still had pressure sores. Even after double the time, the percentage 
still was 68. This is an extraordinarily bad result. But-only a quarter of our cases had regularly been turned in section A. Moreover, it must be pointed out that many new pressure sores over the ischium appeared when the paraplegics began to move in their wheelchairs after a long period confined to bed.

Infections of the Urinary Tract

TABLE VI

Grades of Cystitis and Pyelitis

\begin{tabular}{|c|c|c|}
\hline & $\begin{array}{c}\text { Section } \\
\text { A }\end{array}$ & $\begin{array}{l}\text { Section } \\
\text { B }\end{array}$ \\
\hline $\begin{array}{l}\text { Paraplegics with } \\
\text { no pathological changes in their urine or } \\
\text { not mentioned . } \\
\text { findings of slight urinary infection . } \\
\text { moderately severe acute or chronic cystitis } \\
\text { cystopyelitis. }\end{array}$ & $\begin{array}{r}2 \\
4 \\
32 \\
\mathrm{I} 2\end{array}$ & $\begin{array}{r}4 \\
7 \\
27 \\
\text { 12 }\end{array}$ \\
\hline . . . & 50 & 50 \\
\hline
\end{tabular}

Efforts to limit the infection of the urinary tract were not very successful in sections A and B. More than three-quarters of our cases had had moderately severe or very severe cystitis or cystopyelitis (stage III $78 \cdot 0$ per cent.).

For comparison one could take some examples out of Munro's paper (Munro, 1954) dealing with complete paraplegics. This author found that 24 out of 77 paraplegics $(3 \mathrm{I} \cdot \mathrm{I} 2$ per cent.) had severe urinary infection at least until one and a half years after their discharge from hospital. But as the various periods of time since the beginning of the paralysis did not correspond with our two groups comparison is limited. A comparable figure, given by Guttmann (1963) is 36.4 per cent. of patients with urinary infection on discharge: 'Urethral fistulae are not as rare as one might wish in hospitals not specialised in paraplegics.' This deplorable experience of Houssa and Tricot (1959) was confirmed by our material.

During section A, I I of 34 male paraplegics (32.4 per cent.).

During section $\mathrm{B}, 7$ of 34 male paraplegics ( $2 \mathrm{I} \cdot 2$ per cent.) had urethral fistulae.

The preventive treatment of taping the catheter to the abdomen, as some authors recommend (Comarr \& Bors, I95I; Boshamer, I960), had not yet been carried out in our cases, except in a few paraplegics, who were treated in special wards.

There was a large number of abscesses of the urinary tract in both sections. Thirteen out of 34 male persons (38.2 per cent.) suffered from epididymitis or orchitis. In section B one case developed a hydronephrosis, caused by a urethral stricture.

We regret that the results concerning lithiasis of the urinary tract give only an incomplete picture. Routine X-rays had been done only in special urological wards or departments. This is one reason why calculi of the urinary tract were not 
observed completely and at an early time. Calculi in bladder, kidney or ureter were found

in section A 12 times in 34 male paraplegics ( 37.5 per cent.),

in section B 12 times in 34 male paraplegics ( 37.5 per cent.).

Once more we compare this with the 77 cases of complete lesions published by Munro (I954). His figure of $\mathrm{II} \cdot 7$ per cent. is remarkably low.

\section{THE STANDARD OF PHYSICAL TRAINING}

In this paper the words 'standard of training' mean the whole of the physical efficiency of the paraplegic at stages II and III. In all our paraplegics there was no paralysis of the arms but complete paralysis of the legs. That is why we shall emphasise the performance of the unaffected and compensating muscles of shoulders, arms and trunk. The level reached may demonstrate the degree of the paraplegic's independence. We recorded these results at stage II, a time at which the rehabilitation should have been finalised, and also at stage III, when this period was doubled.

TABLE VII

Standards of Training in 50 Paraplegics

\begin{tabular}{|c|c|c|}
\hline & $\begin{array}{c}\text { Stage } \\
\text { II }\end{array}$ & $\begin{array}{c}\text { Stage } \\
\text { III }\end{array}$ \\
\hline \multicolumn{3}{|l|}{ With or without assistance able to: } \\
\hline Sit up in bed & 36 & 42 \\
\hline Dress themselves & 24 & 37 \\
\hline Sit in or get into chairs or wheelchairs & 24 & 36 \\
\hline Walk or stand with braces & I0 & 17 \\
\hline Manage stairs with braces & - & 4 \\
\hline
\end{tabular}

Our results demonstrate extraordinarily slow progress of physical rehabilitation in many cases. Only after twice the average time of treatment did nearly 75 per cent. of our cases reach the lower standards of training, such as sitting up in bed, putting on their clothes with or without assistance and getting into a sitting position or moving about in their wheelchairs. In contrast to this, the more difficult standards of training, such as standing or walking with braces were reached in only $34^{\circ} \circ$ per cent. of our cases. To enlarge the limits of these training standards, we also counted all the paraplegics who had just begun their training or had been fitted out with temporary plaster shells. Very often these paraplegics lost their ability to walk later on. Only 8 per cent. of the cases were able to manage stairs.

It might be interesting to quote the statistics of Munro (I950) for comparison. Out of his 94 completely paralysed patients 6I (64.9 per cent.) were ambulant, when they left hospital. Boshamer (I960) reports that there have been 23 out of the 44 completely paralysed patients who learned to move about with braces.

The Duration of Treatment-Considering the numerous complications and the defects during training, it is not surprising that at the end of the standard 
rehabilitation period (stage II) only 6 out of the 50 paraplegics were discharged from the hospital. According to Guttmann these average times of treatment are rarely exceeded in the Spinal Injuries Centre in Stoke Mandeville. However, this can only be achieved when the patients are admitted to the centre immediately after the injury. In our cases, only $\mathrm{I} 3$ of the 50 were discharged after twice the average time (stage III).

Social Rehabilitation. Of the $\mathrm{I} 3$ discharged patients, I2 (stage III) returned to their families; one of the cases was transferred to a hospital for incurables. At stage II none of our discharged paraplegics was at work. At stage III, only one paraplegic girl continued her interrupted school education; she worked at home on a correspondence course. Later on she passed an examination for especially talented people and is now a student in the last half-term at the 'Pädagogische Akademie'. She wants to become a teacher in a school for crippled children.

\section{DISCUSSION}

Most of our results were unsatisfactory. In spite of various efforts on the part of the physicians and the nursing staff concerned, the typical complications of paraplegia occurred much too often and too seriously. This applies in particular to the contractures of the joints, which surprisingly were found as often in flaccid paralysis as in spastic ones. These contractures are particular proof of insufficient nursing and lack of regular physical therapy.

The high percentage of pressure sores in our cases is another proof for the necessity to turn the patient at regular intervals (Guttmann, I945, 1953, 1959; Neubauer, I953; Heipertz, I957; Bürkle de la Camp, I959; Houssa \& Tricot, I959; Lindemann, 1960). Only a quarter of our cases were turned regularly because of the catastrophic lack of nurses in Germany. Only a few of the paraplegics were instructed about the importance of their own efforts to avoid pressure sores by being pressure conscious (Guttmann, 1953, 1956a; Kreusch et al., 1957).

The various infections of the urinary tract (cystitis, pyelitis, abscesses) also show the consequences of the insufficiently trained and less conscientious nursing and medical staff. The same applies to the causes of urethral fistulae. The rather large number of stones in the urinary tract-quite apart from the concentration of urine, the stasis and the infection-is to be attributed to the extremely long recumbency. Conversely, the bedrest was prolonged by the various complications developing. The paraplegics began their training in a wheelchair, standing and moving about, at a very late date. Moreover, the paraplegics did not drink more than the normal quantity of liquid. Most of them did not know that sufficient liquid would help to prevent stones. Others limited their liquid consumption to avoid 'wetting'.

The frequent and severe complications mentioned above, decisively influenced the standard of training of the patients. This training standard was still low at the aimed-at end of rehabilitation (stage II). Eventually the paraplegics reached the simpler degrees of training. Only a third of the cases became ambulant after twice the average period of rehabilitation.

The many complications and the low standard of training prevented discharge from hospital at an appropriate date. In some patients the decisive factor for their early discharge was by no means the favourable result of their medical and social rehabilitation. Apart from certain psychological, social and domestic factors, it 
was a defeatist attitude towards the value of rehabilitation which motivated their discharge prematurely. In some cases the opinion was held that the spinal paraplegic's life expectancy was short anyway and, therefore, it was better to spare him from further hospital care and to send him home. Similar views were also expressed by relatives when requesting the discharge of the paraplegic from hospital.

Considering this situation it is, therefore, not surprising that social and professional rehabilitation is very rare in our cases.

The real cause of this accumulation of medical and social inefficiency is inadequate early medical treatment in small as well as large surgical orthopaedic and neurological departments of general hospitals in 86 per cent. of our cases. Evidently these existing institutions could not adequately deal with all the aspects that the treatment of paraplegics demands. This experience confirms the frequently published view that the great difficulties in the rehabilitation of paraplegics can only be overcome in specialised spinal centres.

\section{SUMMARY}

This paper deals with the results of the observations made in the German Federal Republic on 50 spinal cord lesions with complete, irreversible paraplegia. To obtain comparable results, the results were assessed in two fixed stages: one at the end of the accepted average time of treatment and the other at twice the time.

As all paraplegics had been paralysed in the years 1952-58, specialised early treatment in special wards or departments was not available in 86 per cent. of our paraplegics. A combination of inadequacy in medical and nursing personnel, facilities and organisation very often prevented a competent early medical treatment. The reported figures about frequency and extent of complications in paraplegia confirm this experience.

The inadequacy of early treatment had a markedly negative effect on the later standards of training and the occupational rehabilitation of our paraplegics. We hope very much to help our paraplegics more effectively in the near future by completing and enlarging those departments which were recently started in our country.

\section{RÉSUMÉ}

Voici les résultats des études catamnestiques faites en Allemagne de l'ouest à 50 lésés de la moëlle épinière. Il s'agit des paraplegiques avec des lésions complètes et irréversibles. Pour atteindre des résultats comparables on a noté l'état à deux termes fixes: $\mathrm{I}$. à la fin d'un certain temps de traitement en clinique et de rééducation et de réhabilitation comme il est généralement reconnu aux experts; 2. à la fin d'une période double.

Comme les paraplégies dataient des années 1952-58 86\% des cas manquaient d'un traitement préalable dans un hôpital spécial. Un enchainement d'insuffisance soit en personnel, soit de l'organisation, soit des difficultés institutionelles empêchait souvent un traitement médical préalable bien qualifié. La preuve en est la statistique nette et précise du grand nombre et aussi de la dimension des complications des paraplégies. Les défauts du traitement préalable exerçaient au delà une grande et mauvaise influence sur le niveau du training finalement atteint et sur l'occupation professionnelle.

Nous avons bon espoir de pouvoir aider plus efficacement les paraplégiques par la construction et l'élargissement des hôpitaux spéciaux déjà arrangés.

\section{ZUSAMMENFASSUNG}

Es wurde über die Ergebnisse einer katamnestischen Studie an 50 Rückenmarksgeschädigten mit kompletten irreversiblen Paraplegien in der Bundesrepublik Deutschland 
berichtet. Um zu vergleichbaren Ergebnissen zu kommen, wurden die Befunde zu zwei bestimmten Terminen erhoben: nach Ablauf der in Fachkreisen anerkannten durchschnittlichen stationären Behandlungs- und Rehabilitationszeiten sowie nach Ablauf der doppelten Zeitstrecke.

Da die Querschnittslähmungen in den Jahren I952-I958 aufgetreten waren, fehlte noch bei $86 \%$ der Fälle eine Frühbehandlung in einer Spezialbehandlungsstätte. Ein Geflecht von personellen, institutionellen und organisatorischen Unzulänglichkeiten verhinderte daher oft eine qualifizierte medizinische Frühbehandlung. Dies bestätigen denn auch die nüchternen Zahlen über die Häufigkeit und das Ausmaß der Komplikationen der Querschnittslähmungen. Die Mängel der Frühbehandlung hatten darüber hinaus einen entscheidend ungünstigen Einfluss auf das schliesslich erzielte Trainingsniveau und die Berufstätigkeit unserer Querschnittsgelähmten.

Wir haben die Hoffnung, unsere Querschnittsgelähmten durch den inzwischen eingeleiteten Ausbau von Spezialabteilungen bald wirksamer helfen zu können.

\section{REFERENCES}

Boshamer, K. (1960). Zbl. Neurochir. 20, I93.

BÜRKLE DE LA CAMP, H. (I959). Berufsgenossenschaft-Berufsgenossenschaftliche Praxis, 7, $29 \mathrm{I}$.

ComARR, A. E. (1959). Brit. F. Urol. 31, I.

Comarr, A. E. \& Bors, E. (I95I). F. Urol. 66, 355.

Guttmann, L. (1945). Med. Times N.Y. 73, 3 I8.

Guttmann, L. (I953). British History of the second World War. Surgery, pp. 422-516. London: Her Majesty's Stationery Office.

Guttmann, L. (I956a). Dtsch. Z. Nervenheilk. 175, I73.

Guttmann, L. (1956b). Dtsch. med. Wschr. 7, 326-330.

GutTMANN, L. (I959a). Rehabilitation, 30, i 5 .

Guttmann, L. (1959b). Proc. R. Soc. Med. 52, 86.

Guttmann, L. (I963). Paraplegia, I, I78.

Guttmann, L. (1964). 7th International Congress of Physical Medicine, Paris. In press.

HeIPERTZ, W. (I957). Arch. orthop. Unfallchir. 48, 679.

Houssa, P. \& Tricot, A. (I959). Mitt. vom 23.u.24.4.I959 an die E. G. K. S. Dok. Nr. $4409 / 59 \mathrm{~d}$.

JochHeiM, K. A. ; WAHLE, H. (I962). Rehabilitation, 2, 49.

Kreusch, E., Lemberg, K. L. \& Volkmann, F. (I957). Arbeit und Gesundheit N.F. 62, I47-I86. Stuttgart: Thieme.

LindemanN, K. (I960). Landesverband Südwestdeutschland der gewerblichen Berufsgenossenschaften, Heidelberg: pp. 99-I I4.

Meinecke, F. W. (1960). Med. Welt (Berl.) 23, I28I.

Munro, D. (1950). N. Engl. F. Med. 242, I.

Munro, D. (I954). N. Engl. F. Med. 250, 4.

Neubauer, G. (I953). Landesverband Sïdwestdeutschland der gewerblichen Berufsgenossenschaften, Mannheim: pp. I44-I57.

Paeslack, V. (1962). Med. Welt, 28, i 507.

WAHLE, H. (I963). In press.

Wahle, H. \& Bischof, W. (I96I). Fortschr. Neurol. Psychiat. 29, 30 I. 